\title{
EL PASAJE DE LA CIUDAD DE CÁDIZ A LA VILLA DE EL PUERTO DE \\ SANTA MARÍA Y OTROS PASAJES ENTRE LOS SIGLOS XVI y XVII \\ MARÍa Dolores Rojas VACa \\ UNIVERSIDAD DE CÁDIZ
}

\begin{abstract}
RESUMEN: Entre las rentas del Concejo de la ciudad de Cádiz las de los derechos de paso en Santi Petri y Río Arillo y las de los pasajes que comunican con Puerto Real y, en especial, El Puerto de Santa María dan testimonio del vigor cotidiano propio de una ciudad marítima y de aspectos particulares de esta navegación interior en la Bahía de Cádiz así como de las contingencias que afectaron a su servicio. Su estudio parte de 1582, con documentación de la Chancillería de Granada, y de 1596 cuando, tras el saqueo angloholandés, da inicio la documentación municipal gaditana, y continúa con las primeras décadas del siglo XVII, momento en el que Cádiz va sentando las bases de su recuperación.
\end{abstract}

PALABRAS CLAVE: Cádiz, rentas, pasajes, barco luengo, contingencias, pleitos.

\section{THE PASSAGE FROM THE CITY OF CADIZ TO THE TOWN OF EL PUERTO DE SANTA MARÍA AND OTHER PASSAGES (XVI AND XVII CENTURIES)}

ABSTRACT: Among the revenues of the Council of the city of Cádiz those of the rights of passage in Santi Petri and Río Arillo and those of the passages that communicate with Puerto Real and, especially, El Puerto de Santa María, give testimony of the daily vigor typical of a maritime city and particular aspects of this interior navigation in the Bay of Cádiz and the negative incidents that affect your workout. The study with preference begins in 1582, by means of documentation of Chancillería, and in 1596, when the municipal documentation of Cadiz begins after the Anglo-Dutch looting, and continues with the first decades of the XVII century, moment in which Cádiz is laying the foundations of its recovery.

KEYWORDS: Cadiz, revenues, boats leases, luengos boats, incidents, lawsuits.

Recibido: 25-09-2018/Aceptado: 15-11-2018 
De siempre las condiciones naturales de la bahía de Cádiz facilitaron una constante comunicación por mar entre las localidades ribereñas de este arco litoral y, tal es el caso, entre Cádiz y El Puerto de Santa María. Rumbo directo y distancia próxima, sólo en contadas ocasiones se vio obstaculizada por las condiciones del viento y mar o por otras contingencias, como aquéllas derivadas del riesgo bélico o de las frecuentes epidemias.

La opción del trayecto terrestre implicaba, además del tiempo e incomodidad añadida del estado de los caminos hasta bien entrado el siglo XVIII, el inconveniente de tener que salvar caños o "ríos" por medio de barcas. Únicamente el antiguo Puente Suazo, sobre el caño de Sancti Petri y a la salida de la Isla (actual San Fernando), era de antigua fábrica pero, en estado ruinoso, sólo será a partir de la segunda mitad del siglo XVI cuando se dé inicio a un continuado proceso de reparación y mantenimiento que le devuelva su función. ${ }^{1}$ Para atravesar, pues, los cauces en cuestión a pie enjuto era indispensable el concurso de naves. Con ellas el tránsito se hizo regular.

De tal servicio surgió el negocio del pasaje, en sí un transporte de personas y bagajes y un derecho de prestación de paso por el sitio mediante pago con el pretendido beneficio económico para quien lo ejercía. Ya en 1420, por merced de los regentes del monarca Juan II, consta como renta señorial de Juan Sánchez de Suazo, oidor del Consejo real, el disfrute de la casa que disen de la Puente con la barca que cerca della está la qual es en la Ysla de Cádiz. La recompensa no parece desdeñable en relación con el conjunto de la donación, en tal manera que no hay propios algunos que rinda cosa alguna saluo la barca que puede rendir fasta quinientos maravedís de esta moneda..., ${ }^{2}$ y no menos a comienzos del siglo XVI si atendemos al pregón del arriendo de dicha barca hecho en El Puerto de Santa María en $1533 .^{3}$

También Puerto Real obtiene con motivo de su fundación en 1484 merced real para situar su propia barca en río Salado (río San Pedro) y disfrutar del correspondiente beneficio. ${ }^{4}$

\footnotetext{
1 “...Cuando el Rey D. Alfonso la ganó a los Moros, no se pasaba sino por grandes enmaderamientos, que cargaban sobre las ruinas de los estribos. Estuvo así muchos años, hasta que vino a faltar de el todo, pasándose de una parte a otra en barcos con gran trabajo, y mal avío a la provisión, y comercio." CONCEPCIÓN, Fray Jerónimo de la: Emporio de el Orbe, t. II, p. 45. (ed. MORGADO GARCÍA, Arturo), Cádiz, 2002.

${ }^{2}$ En lo concerniente a dicho arrendamiento y a sus iniciales poseedores, véase FRANCO SILVA, Alfonso: La Isla de León en la Baja Edad Media, Cádiz, 1995.

3 "quyen quyziere arrendar la barca, e yerba y salinas de la ysla e puente de León que se dize de Çuaço, la yerba desde el día de San Juan primero que biene en adelante y la barca e salinas desde primero de henero en adelante por tiempo de tres annos primeros siguientes... por el precio que justo sea..." Ibídem, p. 126.

4 "Otrosí por quanto en el camino que va para El Puerto de Santa María ay un río salado nos suplicaste que vos fiziésemos merced para que se pusiese una barca por donde pasasen los vecinos de la dicha villa e los que por ende caminaren e que lo que la dicha barca rindiese que fuese para propios de la dicha villa a lo quel vos respondemos que nos plaze dello e que vos lo otorgamos assí e vos damos licencia para fazer la dicha barca e que lo que rentare agora e de aquí adelante que sea para los propios del dicho concejo de la dicha villa." MURO OREJÓN, Antonio: "III. La Villa de Puerto Real, Fundación de los Reyes Católicos"
} 
Y del mismo modo sucedería con otros servicios como el del paso de Río Arillo, ${ }^{5}$ límite natural entre Cádiz y La Isla de León, el del río Guadalete, junto a la ribera del Puerto de Santa María ${ }^{6}$, y, costeando, una cómoda comunicación de Chiclana ${ }^{7}$ con Cádiz mediante faluchos ${ }^{8} \mathrm{o}$, las más veces, si era por tierra, valiéndose de una barca que atravesaba la desembocadura del canal de Sancti Petri. ${ }^{9}$

La ciudad de Cádiz, ceñido su perímetro por el mar, haría incluso uso de barcas para comunicar lo poblado con la ermita de San Sebastián, situada en el islote inmediato que cierra el cabo más occidental de la Caleta. ${ }^{10}$ Salvo en la bajamar, llegar a pie en seco era inviable pues todavía no se había provisto de un acceso continuo y seguro ${ }^{11}$ que salvara la crecida de las pleamares, aún durante el siglo XVIII pese a disponer ya de castillo y guarnición. ${ }^{12}$ Así, vía y no barrera, el mar era el vínculo que, gracias a barcos de pequeño y mediano porte, enlazaba regularmente la ciudad con las villas próximas de El Puerto de Santa María, ${ }^{13}$ Puerto

en Anuario de Historia del Derecho Español, Madrid, 1950, p. 755.

5 "El caño (de Arillo) tiene una barca por donde pasa la gente que no quiere rodear el camino hasta do no llega el caño, en el cual (entre la bahía y la barca) hay dos molinos...". HOROZCO, Agustín de: Historia de Cádiz, p. 176. (ed. MORGADO GARCÍA, Arturo), Cádiz, 2000.

6 "Se han hecho recientemente dos famosos puentes de barcas para los dos brazos de Guadalete que hay que atravesar en esta distancia de dos leguas, llamado el primero rio de San Pedro...Se compone de nueve barcas, con piso de tablones encima... se hizo el año de $1790 \ldots$ Continuando desde aquí a dicho Puerto de Santa María, se pasa el segundo puente ántes de entrar en la Ciudad. Se compone de siete barcas entramadas..." en PONZ, Antonio: Viage de España en que se da noticia De las cosas más apreciables, y dignas de saberse, que hay en ella, Madrid, 1794, tomo XVIII, Carta Segunda, n. 8 y 9.

7 "De la puente abajo... entra en este río por bajo de la puente otro más pequeño que pasa por la villa de Chiclana, hasta adonde sube la marea, y navegan barcos;" HOROZCO, op. cit. p. 112.

8 "El pasaje de falúas, era un medio de transporte a través del río Iro y caño de Sancti Petri hasta Cádiz. El duque llevaba una parte de lo cobrado por el mismo." en BOHÓRQUEZ JIMÉNEZ, Domingo: Chiclana de la Frontera. Geografía, Historia, Urbanismo y Arte, Cádiz, 1996, pp. 210 y 211.

9 “... y ser el pasaje de la barca que dice al oriente de la isla junto a la isleta de Sancti Petri, por la cual barca se pasa desde Cádiz a la villa de Chiclana." HOROZCO, op.cit. p. 3. BOHÓRQUEZ, Ibídem.

10 "El cual se forma de un muy estrecho gijón de tierra entre el mar, y la Caleta de Santa Catalina, cuyas aguas estrechan tanto la Isleta que forma esta punta, que ha sido necesario repararlo para darle comunicación, y paso; aunque como estrecho de hasta dos varas, y media, se cubre en las crecientes de las mareas..." CONCEPCIÓN, op. cit., t. II, p. 319.

11 "El capitán Lorenzo de Herrera dixo que esta çiudad no tiene otra salida si no es el campo de la Hermita de San Sebastián y que en el passo dél se juntan las dos mares y no se puede pasar a la dicha hermita y con poco que se gaste se puede hacer una puente alcantarilla que sea perpetua por donde se pueda pasar e ir a la dicha Iglessia ...” A(rchivo) H(istórico) M(unicipal de) C(ádiz), A(ctas) C(apitulares), C(abildo) de 28 de enero de 1617, L(ibro) 9, f(olio). 33r(ecto).

12 Concertada la obra del faro de San Sebastián en 1767, “... y en lo posible se irán desmontando los picachos o puntas de peña para que quede un camino de a pie transitable hasta el Castillo y, tal vez con el propio arranque, se proseguirá un canal que, para fines del Real Servicio, se empezó en tiempo del Capitán General de Provincia, Conde de Rodeville (Conde de la Roy de Ville, Capitán General en 1737)...” PÉREZ MULET, Fernando: "La linterna del castillo de San Sebastián en Cádiz. (Notas de un expediente notarial)", Trivium, núm. 8, 1996, p. 108.

13 "El rio Guadalete se introduce en la Bahía por el lado meridional de la misma Ciudad, en la cual se embarcan los que quieren ir a Cádiz por mar, que son los mas; pues solo dista tres leguas, que en tiempo favorable se suelen navegar en una hora...", PONZ, Antonio, op. cit., Carta Segunda, n. 17. 
Real, ${ }^{14}$ Chiclana y, más ocasionalmente, Rota. ${ }^{15}$

Tan manifiesta insularidad impulsaría, por necesidad, el uso regular de estas comunicaciones y éstas constituirían antes que después, prescindiendo de las obligaciones y réditos de una explotación directa, una más de las rentas del Concejo gaditano. Y como tal proprio la ciudad iba a disponer de la facultad de arrendar a particulares la explotación de este servicio, el pasaje, siguiendo una práctica que, con la condición de monopolio, tenía larga trayectoria en la administración pública. Así, pues, los pasajes para ir al Puerto de Santa María y Puerto Real ${ }^{16}$ y los barcajes para cruzar el río de Sancti Petri y Río Arillo serían los inicialmente administrados por el concejo gaditano. Constituían, en todo caso, una nada desdeñable parte del total de propios con que se financiaba la ciudad.

Hay una manifiesta referencia al primero de ellos en la vista que de Cádiz plasmó Georges Hoefnagel no más tarde de $1570 .{ }^{17}$ En panorámica el arco de la bahía y priorizando la banda del mar en línea con el caserío, cobran protagonismo dos naves de un solo mástil,

${ }^{14}$ Hay referencias históricas, documentadas, y oportunas citas bibliográficas a los pasajes en la Bahía de Cádiz desde el siglo XV hasta el presente y, expresamente, al pasaje de El Puerto de Santa María hacia Cádiz. Véanse IGLESIAS RODRÍGUEZ, Juan José: "Señores y vasallos: las relaciones entre la Casa Ducal de Medinaceli y El Puerto de Santa María en la Edad Moderna", Revista de Historia de El Puerto, n 2, 1989, pp. 27-57. (Nueva edición en Monarquía y nobleza señorial en Andalucía..., Sevilla, 2015, p. 97). PÉREZ FERNÁNDEZ, Enrique: De El Puerto a Cádiz. Los barcos del pasaje en la Bahía de Cádiz (Siglos $X V$-XXI), El Puerto de Santa María, 2017. Respecto al pasaje de Puerto Real a Cádiz véase GUTIÉRREZ, Bartolomé: "Historia... de Xerez de la Frontera", Libro 3º Jerez, 1757 p. 221 (ed. 1887, t- II.): "Dos barcas de pasaje que la Villa tiene, de que el Rey les fizo merced... la otra es en el Puntal de Matagorda para pasar á Cadiz; esta non gana renta ninguna nin le ha ganado, salvo tenemos la merced de SS.AA. é non la queremos perder." En 1523 hubo pleito entre la ciudad de Xerez, que pretendía arrendar barca propia con exclusividad en detrimento de la barca portorrealeña que, por real provisión de la reina Isabel "más de quarenta años", según alegaba Puerto Real, ya rendía servicio. A(rchivo) (de la) R(eal) CH(ancillería) (de) G(ranada), C(aja) 5.377, P(ieza) 1.

${ }^{15}$ De estos servicios por parte de Cádiz, en 1668 "había persona que quería hazer postura y tener barco de pasaxe de esta dicha ciudad a la villa de Chiclana...que se mandase pregonar pues hera de utilidad y crecimiento para sus rentas y también...se pregonase pasaje de esta dicha ciudad a la villa de Rota..." AHMC, AACC, $\mathrm{C}^{\circ}$ de 4 de abril de 1668, L 37, f. 229r.

${ }^{16}$ El "común de vecinos trabajadores de las Ciudades de Cádiz, y Puerto de Santa María, hán representado que para pasar de una à otra, y de la primera a la villa de Puerto Real se les hace contribuir con nombre de Renta al tiempo de embarcarse en sus muelles... les es mui onerosa..." Aunque en el transcurso del siglo XVII el servicio se abrirá a más particulares de Cádiz y El Puerto, respetándose los turnos, la vez o barcos de la vez, será en 1743 cuando por R.O. cese esta contribución de los pasajes de la que "no ha avido título de concesión, ni otro que la tolerancia antiquada", aun cuando la ciudad aducía la "antiquada pocessión en que á estado y está de dicha renta..." AHMC, AACC, $C^{\circ}$ de 22 de febrero de 1743, L 99, ff. 61, 64v.-68r. Acerca de su antigüedad, perdidas las ordenanzas, en el citado expediente de 1523: “...lo otro porque mis partes, por servicio de Vuestra Alteza y acrecentamiento de sus rentas, contrataron con la çibdad de Cádiz que oviese pasaje en barcas dende la dicha çibdad a la Mata Gorda, término de Xerez, segund y como lo solía aver dende Cádiz a la villa de El Puerto de Santa María...” ARCHG, Ibídem.

${ }^{17}$ G. BRAUN, Civitates Orbis Terrarum, Primer Libro, Colonia, 1572. Respecto a las capacidades de representación descriptiva, inventarial y analítica de estas vistas portuarias véase ALONSO RUIZ, Begoña y SAZATORNIL RUIZ, Luis: "De San Sebastián a Cádiz: Iconografía urbana de los puertos atlánticos (siglos XVI -XIX)", Anuario IEHS, 24, 2009, pp. 172-175. Igualmente, para Wyngaerde, El Puerto y Cádiz, véase CABALLERO SÁNCHEZ, Miguel-Ángel: "Las vistas de El puerto de Santa María en 1567 de Anton Van den Wyngaerde: pautas interpretativas y análisis de contenidos", Revista de Historia de El Puerto n ${ }^{\circ}$ 41, 2008, pp. 109-147. 
una con vela cuadrada, la otra con vela latina. De poco porte y capacidad comparadas con las vecinas naos y galeras, no se detallan lo suficiente. Pero es significativo que, en relación con la minuciosa imagen de la ciudad, haya señalado expresamente su protagonismo con la cita escrita de Passaige p[ara] El Puerto de S [anta] María. Por su parte, la visión que de la banda de la bahía realiza en 1567 Anton Van den Wyngaerde incide igualmente en una nutrida presencia, junto a los navíos de gran porte, de embarcaciones ligeras similares a la señalada por Hofnagel.

\section{Imagen 1}

\section{Georges Hoefnagel. CADIZ, olim Gades, 1564 (Detalle) $^{18}$}

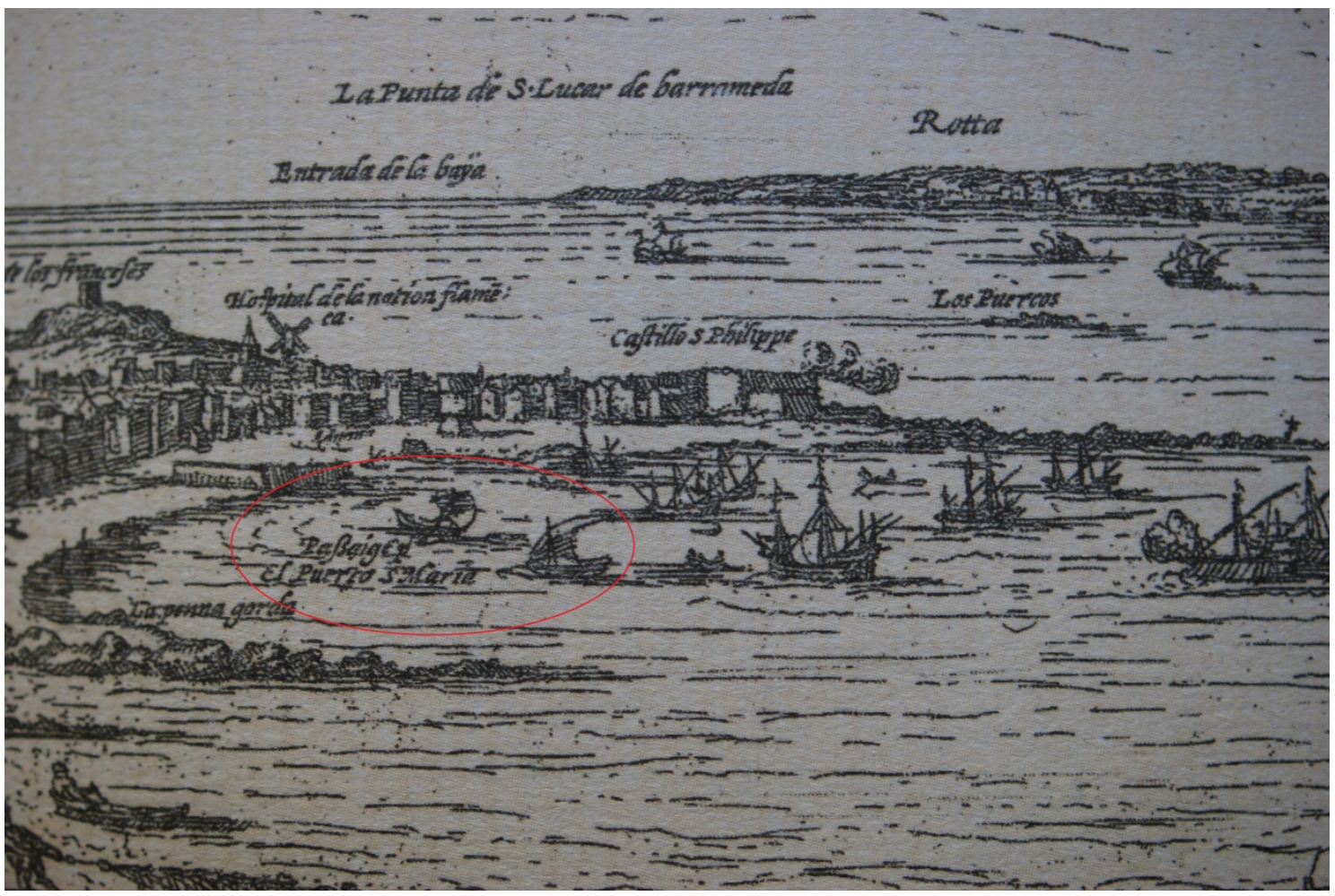

La primera noticia documental de su arrendamiento a la que accedemos es de 1582 merced a un expediente existente en el archivo de la Real Chancillería de Granada. ${ }^{19}$ Parcialmente conservado, a falta de registros municipales gaditanos de la época por causa del saqueo angloholandés de 1596, describe aspectos de esta renta al tiempo que ilustra acerca del lugar y el momento. Su contenido resulta de la apelación efectuada por una de las partes

${ }^{18}$ Reproducido de MARTÍNEZ LÓPEZ, Rosario (ed.): Un mar para la historia de Cádiz: cartografía y estampas de la biblioteca de D. Federico Joly Höhr (S. XVI - S. XIX). Cádiz, 2000, lám. I, pp. 66 y 242. ${ }^{19}$ ARCHG, C 3.378, P 8. 
litigantes en desacuerdo con una sentencia previamente emitida en Cádiz tras el pleito suscitado entre el Concejo gaditano y el arrendatario de dicho pasaje. ${ }^{20}$

En efecto, en enero de 1582 salía a concurso, entre otros, el servicio en cuestión. Aunque un vecino, Juan Ibáñez, hizo postura o pujó el día 6, con expresa declaración de barcos e pasaje que a de dar tal arrendadorpara yr a la dicha willa del Puerto, el 21 del mismo mes se remataba públicamente en la plaza de la Corredera, en presencia del escribano del cabildo, regidores y por voz de pregonero público por mandado de los dichos señores, en otra postura mejor, la de Pedro de Alcocer, vecino y mayor postor, quien se obligaba como principal deudor, y en los mercaderes Antonio López y Andrés Rodríguez, también vecinos y ambos en calidad de fiadores. ${ }^{21}$ Pedro de Alcocer, pues, al tiempo que prometía cumplir las condiciones ofrecidas por el primer postor, Juan Ibáñez, asumía la mejora del precio puesto a este arriendo concejil, 650 ducados por dicho año completo menos la rebaja de otros 12 ducados de prometido, como se contiene en la postura que tiene en este libro de rentas, los cuales se descuentan al término del cobro al que se compromete.

A tal fin, Alcocer, López y Rodríguez se obligaron a pagar la tercera parte (216’5 ducados más 62 maravedíes), por los terçios del año que son fin de abril e fin de agosto e fin de dizienbre, cantidades que les deberían resultar sobradamente inferiores al uso y consiguiente beneficio del pasaje durante los doce meses del año estipulado.

Igualmente se obligaban al resto de expuestos con los que se arrienda esta dicha renta, condiciones que están escritas en este libro de rentas y en el capitular de los fechos desta çiudad, como en ellas se conthiene, porque las an visto, sauido y entendido y son ziertos sauidores dellas. Quedaba expresamente escrito que no aducirían desqüiento della por razón de qualesquier enfermedades de peste u otras qualesquier que en esta çiudad, lo que Dios no quiera, subzeda, ni enbargo de naos e nauios o barcos ni por otro qualquier caso fortuito, divino o vmano, ansi de tenporales malos como de otros que subzedan, aunque sea de los casos que acaezen una vez en mill años que de ningún remedio de los que se pudieren aprouechar no quieren pedir desqüento alguno.

Por tanto, en dicho arrendamiento se cumplía la normativa al uso o forma que se ba de tener en arrendar los propios, y rentas de los Concejos. ${ }^{22}$ Los actos subsiguientes, mediante el refrendo del documento por los actuantes, aseguraban la legalidad y fuerza contractual del hecho, su

20 “... en Cádiz... la principal justicia es un corregidor... para el demás gobierno y administración de ella acompañado de un alcalde mayor letrado, con alguacil mayor y otros dos menores que él nombra y pone, cuya jurisdicción se extiende, como se ha dicho, en el expediente y judicatura de todas las causas civiles y criminales... De las causas de que hay apelación se acude a la real chancillería de Granada por ser Cádiz de su distrito." HOROZCO op.cit., p. 82.

${ }^{21}$ Apéndice documental $n^{\circ} 1$.

${ }^{22}$ N(ueva) R(ecopilación), Lib. VII, Tít. V, L. IV. 
garantía por ambas partes y, con la rendición de cuentas cada cuatro meses o tercias, la seguridad del pago por los arrendatarios y su cobro por parte del arrendador, el Concejo de Cádiz en este caso. Previamente se había puesto de manifiesto el concurso mediante sucesivos pregones, especificando obligaciones, condiciones y fianzas en el lugar habitual de la ciudad, plaza de la Corredera, enfrente del Cabildo, y al tiempo transcurrido indicado se había adjudicado al mejor postor tras la necesaria subasta pública. La posterior carta de obligación de pago dejaba constancia de los plazos estipulados y las cantidades acordadas así como de las habituales cláusulas, renuncias y firmas de los intervinientes. De esta forma, en fin, la ciudad se hacía con el documento e instrumento legal que, ante posibles eventualidades, le asegurase recibir regularmente las cantidades fijas negociadas en la formalización del acuerdo o, en su caso, al término del contrato. ${ }^{23}$

Sin embargo, no deja de sorprender lo aventurado de las condiciones asumidas por los postores del pasaje, exponiéndose no sólo a la consabida variabilidad del tiempo que, si bien episódicamente, propiciaba más de un desatado temporal sino, también, al posible trance de la guerra y piratería, en uno y otro caso provocando el cese de la navegación, ${ }^{24}$ o a la probabilidad y consecuencias de un brote epidémico que impondría, mediante cuarentena vigilada, estricta incomunicación.

Y sucedió. Entre 1580 y 1583 Andalucía se vio conmocionada por epidemias periódicas, bien fuesen de peste bubónica, en casos, bien de tabardillo o fiebres tifoideas, ${ }^{25}$ suerte de la que Cádiz no iba a escapar. ${ }^{26}$ Así, pues, el caso fortuito divino o vmano surgió al declararse, como es público y notorio, el 16 de abril, muncha enfermedad del mal contajioso de peste y murieron en ella munchas personas y ono ospitales y casas de convalezientes, decurso que se prolongaría hasta el 27 de agosto, una vez que oficialmente se declarase extinguida. Fueron cuatro meses más diecisiete días de aislamiento, el equivalente a todo un tercio del año contratado, tiempo

\footnotetext{
23 Aunque referido concretamente a los arrendamientos de escribanías públicas y señoriales, puede aplicarse igualmente a éste del pasaje. Véase PARDO RODRÍGUEZ, María Luisa: Señores y Escribanos. El Notariado andaluz entre los siglos XIV y XVI, Sevilla, 2002, pp. 38-44.

24 “....y para advertir à los que tuvieren sus Navíos en la Baì, que sea con el cuydado, y prevencion que pide el considerar que no estan en Puerto, puesto que ni tienen seguridad de los tiempos, ni de los enemigos, sino es surgiendo de Puntales adentro, que alli es menos el riesgo." Esta recomendación, aunque interesada a favor de Sevilla y ya de la segunda mitad del siglo XVII, respondía a la realidad. VEITIA LINAJE, José de: Norte de Contratación, Lib. I, Cap. XXV, n. 32.

${ }^{25}$ CARMONA, Juan Ignacio: Enfermedad y sociedad en los primeros tiempos modernos, Sevilla, 2005, pp. 86 y 87.

26 "Varias veces ha molestado esta Isla, y Ciudad el cruel azote de el Contagio... La primera Peste, que afligió a esta Ciudad, fue la de el año $1507 \ldots$ La segunda fue el año de 1582 siendo Obispo D. García de Haro, y Corregidor D. Juan de Alarcón Señor de Almodóvar de el Espinar, que atento el beneficio de la salud recibida por intercesión de S. Roque, solicitó con el Regimiento la erección de una grande y hermosa Ermita, que se le dedicó dicho año..." en CONCEPCIÓN, op.cit., t.II, pp. 209 y 319.
} 
improductivo por la inactividad a la que el barco del pasaje, que della va de ordinario, se vio obligado, dado que El Puerto había adoptado la prudente decisión de cerrar el trato e comunicazión, entrada e comerzio de la dicha villa a esta çiudad, norma habitual en cualquier otra localidad que se viera afectada. ${ }^{27}$

No hubo forma de sortear este bloqueo naval en el que intervinieron, con la autoridad del Marqués de Santa Cruz, D. Álvaro de Bazán y Guzmán, residente entonces en la villa señorial en calidad de Capitán General, los mismos vecinos portuenses, según se desprende de las declaraciones insertas en el proceso. Los arrendatarios, los dichos Andrés Rodríguez y Antonio López más otro que, en ausencia no explicada de Pedro Alcocer, se les había sumado al negocio, Aparicio Rodríguez, expusieron que, cargados de jente como es costunbre, a la altura de la barra en la entrada de El Puerto fueron interceptados por dos fregatas con jente armada con arcabuzes y obligados a tornar rumbo a Cádiz dicho pasaje con la jente que dentro Ilenana.

Era sustancialmente lo mismo que los testigos aportados por ellos, también vecinos de Cádiz, vinieron en añadir a la declaración. Así, el arráez del barco luengo del pasaje, Pedro Domínguez, habla de una fragata con más de veinte arcabuzeros y de parte del Marqués de Santa Cru₹: Un vecino, Pedro Díaz, declara que, encontrándose cerca del molino de biento, acudió un grupo de soldados de parte del Marqués y que requirieron del arráez que se volviese y que tanpoco echase gente en Santa Catalina del dicho Puerto de Santa María. Y queriendo echar la dicha gente en la dicha Santa Catalina vino una fregata tras del dicho pasaje y, viéndoles venir la fregata, dio la vela y se vino a esta çiudad. El boticario Alonso Rodríguez se manifiesta en similares términos al igual que otro pasajero más, Diego de Castro, porque se guardaban desta çiudad del mal de peste. Finalmente, como el dicho Andrés Rodríguez expone, el 27 de agosto de 1582 es el primer día que se corre el pasaje desta çiudad en la villa del Puerto de Santa María y se cobra el derecho.

Así, llegado el fin del mes de agosto, al no hacer frente al pago de la tercia estipulada, entran en pleito con el Cabildo gaditano. Éste ordena hacer tranze e remate de los bienes executados por la obligada cuantía de los referidos 216,5 ducados con 62 maravedís más las costas en Pedro de Alcocer, en calidad de principal, y en Antonio López y Andrés Rodríguez, su cuñado, como fiadores, todos obligados a mancomún. López pide que la ejecución se haga sobre las casas de su morada que son en esta çiudad en la plaz̧a de la Corredera della y, por demás, señala a su suegro, Manuel Hernández, como garante de que su propiedad y valor son çiertas y valederas a

27 LEÓN VEGA, Milagros: "Incidencia de una crisis epidémica en Antequera: la peste de 1581-83, a través de las actas del Concejo" en Baética: estudios de arte, geografía e historia, nº. 25, Málaga, 2003, pp. 547574. 
la dicha deuda prinçipal y costas y como fiador de su precio, llegado el caso de que hubiera entretanto algún embargo sobre las mismas.

Esta valoración asignada responde a la realidad contractual del mercado del momento y garantiza al Concejo la compensación y, por venta o alquiler, un beneficio seguro pues unas casas con sus almazenes $e$ dos entradas, situadas en dicho lugar, se arrendaban en la nada desdeñable suma de 54 ducados anuales en 1560 y, para 1570, casi diez años después, otras casas, sin duda mejores, en que a el presente bybis e moráis eran arrendadas en 80 ducados anuales durante dos años por sus propietarios, Diego de Aguiniga, regidor gaditano, y Bartolomé de Amaya de Vargas, escribano con oficio en Jerez, al vecino y notable mercader flamenco Martín de Lao. ${ }^{28}$

En todo caso, siendo inminente la ejecución de dichos bienes, Antonio López presenta escrito de oposición en noviembre, en su nombre y en el de sus socios, de los que sólo se cita ya a Andrés Rodríguez y a Aparicio Rodríguez. ${ }^{29}$ Nada se dice de Pedro Alcocer. En 30 de diciembre de 1582, ${ }^{30}$ Antonio López, en la puerta de la cárcel, compulso e apremiado e por remediar su prisión e vexación, sin perjuicio de su derecho y de su apelación y protestos, hace pago de la deuda y de las costas con dos presos en la dicha cárcel por testigos. Liberado el cuerpo, prosigue su apelación ${ }^{31}$ a la Chancillería de Granada a través de apoderados. Mas tal como el procurador Pedro de Olmedo, en nombre del Cabildo, había expuesto con dura precisión, se a de hazer el tranze e remate que tengo pedido sin enbargo de su opusižión porque por esta çiudad que fue la que les arrendó el dicho pasaje no se les puso ynpedimiento en el vso dél para que fuese o viniese a la dicha uilla y sy en la dicha willa del Puerto se les puso ynpedimiento esto no se les aseguró por esta çiudad. Y por razón de la peste no puede pretender el desqüento que pide porque este remedio lo tiene renunz̧iado e qualquier otro caso como por la escritura en que esta oposizión se funda pareze. Incompleto el expediente, nada más vuelve a saberse del pleito ni del desenlace que, de seguro, debió ser contrario a la demanda de López.

Hay que esperar al aciago 1596 para volver a disponer de noticias documentales. En ellas vuelve a aparecer Andrés Rodríguez, vezino desta çiudad, arrendatario, y de quien consta que debe pagar sólo 286.500 maravedíes por los dos últimos tercios del año. El primero ya lo había abonado, cuya qüenta de cargo y descargo se quemó y perdió con la entrada del enemigo inglés en

${ }^{28}$ ROJAS VACA, Ma Dolores: Una Escribanía Pública Gaditana en el Siglo XVI (1560-1570) Análisis Documental, (Arrendamientos y Compraventas), Cádiz, 1993, pp. 167 y 195.

${ }^{29}$ Apéndice documental $\mathrm{n}^{\mathrm{o}} 2$.

${ }^{30}$ El documento se data en 30 de diciembre de 1583 según la era cristiana y estilo de la Natividad que, reducida al cómputo actual, es el 30 de diciembre de 1582.

${ }^{31}$ NR. Lib. VII, Tít. V, L. 5. 
esta çiudad como es notorio y por esta razón se le haze cargo de los dichos dos terçios solamente. ${ }^{32}$ Esta circunstancia de pérdida documental es generalizada, común a otras rentas y, por tanto, con la del pasaje de Puerto Real, a nombre de Antonio Fernández, de cuantía sensiblemente menor a la de El Puerto. Únicamente se le cargan 25.000 maravedíes de los dos tercios porque pagó el primero. ${ }^{33}$

El Cabildo gaditano, consciente de lo acontecido, acuerda una justificada quita de setenta e un mill e ochoçientos y setenta y quatro maravedís que a Andrés Rodríguez se la abaxaron de la renta del dicho pasaje por los meses de jullio y agosto que no ubo veçinos en esta çiudad desde que entró el enemigo inglés y por esta razón se le abaxaron de su qüenta. Y qué argumentos, si los hubo, expusiera Andrés Rodríguez, también 15.000 maravedíes se le abaxaron de la renta del dicho pasaje por la grande quiebra que tuvo por todo el resto del dicho año, por excusar pleitos y por las razones referidas se le bizo la dicha suelta. Ítem más, por aver quedado muy pobre y perdido del robo y saco del enemigo e no poder pagar, en 1597, mediante escritura pública y fiador, Antonio López de nuevo, obtiene espera por cuatro años para pagar lo que debía en tres plazos hasta fin del año de $1600 .{ }^{34} \mathrm{~A}$ saber, a los términos de cada año, 18.700 maravedíes en 1597, 35.953 en 1599 y los restantes 35.954 en 1600. ${ }^{35}$ Igualmente, con el de Puerto Real a Antonio Fernández se le abaxan 8.436 maravedís por la suelta de obligación que la ciudad le hace en dichos meses y le dan plazo, con escritura pública también, hasta Tosantos de 1598 para pagar los restantes 8.869 maravedís de deuda. ${ }^{36}$ En todo caso, desde el desastre y, al menos, hasta noviembre, este arrendamiento no lo había vuelto a administrar ni cobrar, como también sucedía con los demás. ${ }^{37}$

Indudablemente, dadas las diferencias de precios entre ambos, el valor del pasaje de El Puerto de Santa María es muy superior al del pasaje de Puerto Real. La diferencia no vendría dada sólo por la mayor distancia a surcar y la exposición al seno más abierto de la bahía, con más duración y relativo riesgo por tanto, sino, en especial, por el uso, frecuencia y demanda de uno y otro. Por demás, ciertamente, hecha excepción de tan grave acontecimiento, los precios consignados reflejan la continuidad del servicio y, consecuentemente, de su rendimiento. Asignándole al primero de ellos el valor oficial de 375 maravedís por ducado, nos da un montante para 1596 de 1.528 ducados o 573.000 maravedís,

\footnotetext{
${ }^{32}$ AHMC, L(ibro de) P(ropios) C(ádiz), 1596, f. 23v.

33 Ibidem.

${ }^{34}$ Apéndice documental $n^{\circ} 3$.

35 Ibídem, f. $24 \mathrm{v}$.

36 Ibidem, f. 25 r.

37 “....los arrendadores de las rentas desta çiudad de la de la entrada del vino que de fuera parte entra en esta çiudad y noveno del vino y casa de los cabritos, pasaje de Puerto Real, la casa de la mancebía no administran ni cobran las dichas rentas que la çiudad provea de remedio zerca dello o lo que más convenga..." AHMC, AACC, $C^{\circ}$ de 2 de noviembre de 1596, L 1, f. 4v.
} 
de los que habría que descontar una mínima cantidad de prometido, y ello pese a que dicho servicio, en estos años, se solapaba sin destacables conflictos ${ }^{38}$ con el que, de antaño, también prestaba periódicamente en ruta de ida y vuelta y en calidad de propio de las rentas del Duque de Medinaceli dicha villa. Era, pues, impensable que su arrendatario pudiera hacer frente a tan elevada deuda, dadas las consecuencias del referido desastre. Por otra parte, el que entonces se hubiera contratado por esa suma no viene sino a reflejar la previa pujanza comercial de la ciudad y de la bahía en estas fechas así como lo acertado, desde la óptica comercial y estratégica enemiga, de los golpes ingleses de 1587, el de Drake, y éste fatal de 1596 ya que no volveremos a ver tan elevado precio en dicho negocio.

Del arrendamiento del pasaje para la villa de Puerto Real hay relativa continuidad en las posturas hechas, habitualmente, por vecinos de allí. ${ }^{39}$ Así, en 1598, Miguel Prieto y su fiador, Juan Álvarez Paje, regidor gaditano, se obligan por 60 ducados que valen 19.860 maravedís y, pese a lo acontecido, a todo riesgo y ventura, riesgo que corrieron al detectarse en agosto sospecha de mal..$^{40}$ Rodrigo Lorenzo lo pondrá en 100 menos 10 de prometido al año siguiente. Abre el siglo con Antonio Fernández nuevamente en 60 y en 1601, otra vez, Miguel Prieto con 52 ducados, poniendo de fiador a un vecino de Cádiz, Cristóbal Benítez, piloto de la bahía. Alonso Martín se hará cargo desde 1602. En 1603, en la tabla pública donde se pregonaban las posturas, en la plaza de la Corredera, la que había hecho de 55 ducados, rematándosele luego, la cierra con prisas en 60 porque se quiere ir a su casa. En 1604 repite con 55 y, esta vez sí, con expresa condición de discontar a la rata si hubiera enfermedad. ${ }^{41}$ En 1605 se remata por 60 en Francisco Giraldo pero, pasado un mes, pasa a Benito García por sólo 45 ducados ya que Giraldo es muerto y no dio fianzas. Para finalizar, en 1606 el mayordomo de la ciudad, se hace cargo en fieldad del pasaje pues no había postura ofrecida hasta que es Alonso Martín quien, por 50, nuevamente se hace cargo del mismo. En 1607 ya tendrá que subir, ante otras ofertas que han ido pujando al alza, a 150 con 10 de prometido ${ }^{42}$ aunque respecto a este arrendamiento no hay variaciones significativas de precio. En 1615, por

\footnotetext{
${ }^{38} \mathrm{El}$ Concejo gaditano, en 1570 y hasta 1576, protestará por el abuso que hacen al cobrar de más, una vez ya en el mar, a los vecinos de Cádiz que hacen uso de la barca portuense. Véase PÉREZ FERNÁNDEZ, pp. 25 y 26.

${ }^{39}$ El pasaje también era cubierto por la ciudad de Cádiz al menos desde principios del siglo XVI.

${ }^{40}$ Como Jerez y El Puerto de Santa María se guardan de Puerto Real, se facultó al Dr. Diego Arias, uno de los médicos de la ciudad de Cádiz, para que se desplazara allí a ver, al tiempo que quedaban en alerta los diputados de sanidad. Arias dictamina que, muy al contrario, dicha villa está buena y sana de mal contagioso... AHMC, $\mathrm{C}^{\circ}$ de 13 de agosto de 1598 , L1, f. 120v. y C $\mathrm{C}^{\circ}$ de 21 de agosto, f. 120v.

${ }^{41}$ AHMC, L(ibro de) R(entas) C(ádiz), 1597, s.f.

${ }^{42}$ AHMC, LRC, 1605, s.f.
} 
ejemplo, seguía en 50 ducados $^{43}$ y, ya en 1625 , se concertaba en 210 ducados pero por tres años, de 1625 a 1627, a razón de unos módicos 70 anuales. Bien es cierto que entonces Cádiz andaba acuciada por recuperarse de todo lo gastado en fortificaciones y en el donativo hecho al rey de 50.000 reales. $^{44}$

El rendimiento del pasaje de El Puerto de Santa María pronto daría signos de cierta recuperación. En 1597 estaba en 900 ducados, cantidad que liquida definitivamente en junio del siguiente año su arrendatario, Juan López de Meneses. Respecto a 1598 conviene precisar que es el año en el que se intentan recuperar las ordenanzas quemadas y desaparecidas con el inglés, guardándose las encontradas y rehaciendo las destruidas. ${ }^{45}$ En esto la administración del pasaje ya disponía con cierta antelación de un nuevo documento, que era copia o tanto auturizado. ${ }^{46}$ De su necesidad es buena prueba el que, poco después, por evitar los desórdenes que ay en los arrendadores del pasaje del Puerto de Sancta Maria que se vean las condiçiones y se ponga un tanto dellas a la puerta de la mar de la çiudad para que todos vean lo que an de pagar. ${ }^{47}$ En 1598 Andrés Rodríguez vuelve a hacer postura, pero es Tomé Rodrígue $z^{48}$ quien lo arrienda por 1.100 ducados menos 30 de prometido, que valen 401.250 maravedís, obligándose con Juan Bautista de Meneses y Martín Jiménez. ${ }^{49}$ Al igual que con el pasaje de Puerto Real, también asumiendo riesgos extremos, sujetos a necesidad, prometen que no alegarán causa alguna para no los pagar porque la renta la tomaron a su riesgo, peligro y ventura de qualquier caso fortuito pensado o no pensado de enemigos, guerra, fuego u otro... de los nunca vistos que pueden suceder de mill a mill años...

Vuelve Andrés Rodríguez en 1599 por 1.050 menos 100 de prometido. Para este cometido consta la venta por parte de Juan Bautista de Meneses del barco que dizen el barco luengo que es el que sirve de passaje que va desta çibdad a la çibdad del Puerto de Santa María por 100 ducados de a 11 reales cada un ducado al contado. Poca, por muy sucinta, es la descripción que

\footnotetext{
${ }^{43}$ AHMC, AACC, $C^{\circ}$ de 13 de febrero de 1615, L 7, f.249r.

${ }^{44}$ AHMC, AACC, $C^{\circ}$ de 2 de abril de 1625, L 13, ff. 50r. y v.

45 "Dixeron Francisco Fernández de Angulo y Martín de Irigoyen, regidores de la ciudad que... an buscado y allado algunas y de otras tienen memoria, las quales an recopilado borrón con la noticia que dellas an tenido y las an redusido conforme al estado en que al presente está esta ciudad, las quales va escribiendo el escribano de cabildo por el orden que le dan. Los susodichos que esta ciudad en cada cavildo celebrare las mande ver y enmendar y hazer lo que más conviniere... la ciudad acordó que así se haga y se lean... las que estuvieren hechas... den a confirmar de S.M. y asimismo se apregonen..." AHMC, AACC, $\mathrm{C}^{\circ}$ de 13 de agosto de 1598, L 1, ff. 130r. y v.

46 “....un tanto auturizado de las ordenanzas que esta çiudad hizo de la administración del pasaje que va desta ciudad a la del Puerto de Santa María. La ciudad acordó que se guarden y trasladen al libro de las ordenanzas de ciudad." AHMC, $C^{\circ}$ de 16 de enero de 1598, L 1, f. 80r.

${ }^{47}$ AHMC, AACC, $C^{\circ}$ de 22 de septiembre de 1599, L 2, f. 33r.

${ }^{48}$ Con profesión de corredor de lonja. CARRASCO GONZÁLEZ, Ma Guadalupe: Corredores y comercio. La correduría de lonja gaditana entre 1573 y 1805, s.1., 1999, pp. 19 y 48. También en el Padrón de Vecinos de 1605 (transcrito Tomás por Tomé). PORQUICHO MOYA, Isidoro: Cádiz. Población y Sociedad.15971650, Cádiz, 1994, pp. 149 y 154.

${ }^{49}$ Con profesión de lencero. Ibídem, pp. 148 y 157.
} 
da: mástel y vela e timón e remos e xarcia e con todos los demás aparejos que tiene. No indica su capacidad y sí que es el mismo barco que el comprador le vendió anteriormente, ${ }^{50}$ lo cual viene en relación con el arrendamiento del año anterior cuando Meneses se obligó con Tomé Rodríguez. El precio era el adecuado al momento pues un barco luengo para uso pesquero se vendía en dicha fecha por 80 ducados. ${ }^{51}$

En marzo del siguiente año hay nuevo arrendador, Pedro González de Noruega, vecino de Cádiz, con el mismo Meneses de fiador, por 1.050 ducados menos 50 de prometido y, haciendo mención por primera vez de su existencia e inclusión en la normativa, con las condiciones de años pasados y la ordenanza que de nuevo se a hecho de que an de enbarcar y desenbarcar en el muelle, ${ }^{52}$ frente a la Puerta del Mar. Dado en fieldad el contrato, pone como definitivo fiador a Bernabé Rodríguez, quien señala como garantía dos casas, una en la calle de San Francisco y otra en el Campo de la Jara. De estos 1.000 ducados habrá que esperar a noviembre de 1602 para su definitiva cancelación, previo litigio, por 719 ducados o 5.603 reales que es la rata de seis meses y tres días. ${ }^{53}$ Desconociendo las alegaciones hechas por González, cabe pensar que, como en 1582, la epidemia sobrevenida en 1600 afectara negativamente el rendimiento del pasaje y que aquél exigiera el correspondiente proporcional descargo, evidentemente sin éxito.

Así, en 1601 se remata en Francisco Hernández por sólo 500 ducados menos diez de prometido pero el servicio ofrecido acaba por provocar más adelante las quejas de los vecinos pues no hay pasaje como sienpre le a tenido y que, aunque al presente no le tiene, se cobra por Francisco Hernández, que dize lo tiene en fieldad la renta, excesivos preçios. La ciudad toma entonces cuenta de lo que se había cobrado y pregona nuevamente si hay quien quiera hacerse cargo y poner barco que vaya y venga y sirva de pasaje. ${ }^{54}$ La cuestión es que la epidemia de peste que, por tiempo de diez meses, está castigando la comarca, obliga a cerrar toda comunicación, ello al margen de una alerta dispuesta ante el aviso de una posible flota enemiga. ${ }^{55} \mathrm{Ya}$ en noviembre, con

\footnotetext{
${ }^{50}$ Apéndice documental $n^{\circ} 4$.

51 Alonso Rodríguez, calafate, y Martín de Astorga venden a Pedro Espíndola un barco "que es barco luengo de pesquería... en la ribera desta çiudad... por 80 ducados de a 11 reales cada ducado.” AHPC, P(rotocolos) N(otariales) C(ádiz), oficio 9, legajo 1510, ff. 351v.-352v. Cádiz 28 Abril 1599.

52 AHMC, LRC, 1597, s.f. El muelle coincide con el que aparece trazado en la planta de Cádiz de 1609. CALDERÓN QUIJANO, José Antonio: Cartografía Militar y Marítima de Cádiz 1513-1878, Sevilla, 1978, vol. I, pp. 125-127 y vol. II, fig. 143; RUIZ NIETO-GUERRERO, Ma Pilar: Historia Urbana de Cádiz. Génesis y formación de una ciudad moderna, Sevilla, 1999, p. 44. (En nueva edición, RUIZ NIETOGUERRERO y JIMÉNEZ MATA, Cádiz, 2016, p. 52).

${ }^{53}$ AHMC, LRC, 1597, s.f.

${ }^{54}$ AHMC, AACC, $C^{\circ}$ de 28 de septiembre de 1601, L 2, f. 328v.

${ }^{55}$ AHMC, AACC, $C^{\text {o de }} 4$ de mayo de 1601, L2, f. 296r. "La ciudad acordó que los regidores a quien tocare guardar las puertas y entradas desta çiudad asistan el día que fueren no encomendándolo a nadie pues tanto conviene a todos y a esta república que tenga y se conserve en salud y asimismo acordó que se cierre el
} 
motivo de acordar el pregón de las rentas para el inmediato año próximo, el Cabildo trataba nuevamente la cuestión y, consciente de que nadie pujaría por lo que restaba del año, volvía a rematarla en Francisco Hernández. Mal responde éste ya que, por no pagar la correspondiente fianza, no hace otra sino esconderse con lo que cesa definitivamente el servicio. ${ }^{56}$ En diciembre, pues, se trata en cabildo de la incomodidad que hay en la falta de no tener esta çiudad barco que servía de pasage que vaya al Puerto de Santa María porque los yentes y vinientes y veçinos desta çiudad no hallan pasage a sus horas señaladas como sienpre se ha tenido demás de la pérdida que a esta çiudad le viene de la renta. El acuerdo inmediato al que se llega es el de enviar a alguien a buscar un barco adecuado a Sanlúcar, puerto conocido por la bondad de sus barcos luengos, $y$ otras partes donde lo oviere $y$ se hallare. ${ }^{57}$

Tras este último episodio, abre 1602 con la exigua postura de Pedro de Zurbarán por 400 ducados, con 50 de prometido y, por fin, con condiçión que si durante dicho año se zerrare la entrada del Puerto con Cádiz o esta çiudad con la del Puerto... se le a de discontar ... el tienpo que por la dicha razón no fuere el dicho pasaje...", cláusula que, por supuesto, también expresa Benito Sánchez, quien lo obtiene junto a su fiador, Gonzalo Hernández, ${ }^{58}$ por 600 ducados y la rebaja de otros 50. Ambos se hacen cargo de la fieldad y cobranza del pasaje en 1603 por 600 ducados con las habituales condiciones y además, expresamente citada, la de tener libro de qüenta y razón de lo que cayere para darla cada que se pida y, de nuevo en 1604 por 760 ducados. Al siguiente año otro vecino, Alonso de Figueroa, la pone en 900 y, en 1606, por igual monto Francisco Sánchez Gallardo ${ }^{59}$ aunque con peor fortuna. En febrero de 1607, preso en la cárcel de Cádiz, apela a la Chancillería granadina y en su alegación cuestiona el precio del arrendamiento. Así, en el escrito presentado por su procurador señala que al tiempo del remate no valía ni 500 y que respecto de los temporales y malos tienpos que vbo el dicho año no vbo passages e mi parte perdió en la dicha renta más de 600 ducados y gastó más de 2.000 reales de su propia bacienda teniendo de gasto en cada un día 44 reales y medio con cinco hombres que traýa en el barco y tres reales que pagaba del barco en cada día. Y, encima, por que no hubo galeones ni vinieron flotas por haberse perdido... no pudo valer la dicha renta los dichos 500 ducados y por 2.000 y 500 reales que mi parte le está debiendo le tienen preso ${ }^{60}$.

Boquete con sus puertas que no pueda entrar por él ninguna gente ni barcos... los diputados de la sanidad busquen una barqueta para que ande en la mar y tenga buena guarda y custodia para que no alsen en tierra ninguna gente de Sevilla ni Sanlúcar y que no les consienta estar en la baýa..."; f. 297r. y v. "El dicho Martín de Irigoyen, regidor, dixo que en el rebato de nueva de armada enemiga que vino en esta çiudad en veinte y dos de abril se despacharon correos...para que la socorriesen si uviere necesidad..."

${ }^{56}$ AHMC, AACC, $\mathrm{C}^{\text {o }}$ de 2 de noviembre de 1601, L 2, ff. 337v.-339r.

${ }^{57}$ AHMC, AACC, $C^{\circ}$ de 16 de diciembre de 1601, L 2, f. 351v.

${ }^{58}$ AHMC, LRC, 1597, s.f. Gonzalo Hernández era, de profesión, mercero. PORQUICHO MOYA, op.cit.

${ }^{59}$ AHMC, LRC, 1605 , s.f.

${ }^{60}$ ARCHG, C 1.359, P 9, s.f. 
En las probanzas consiguientes los testigos presentados por Gallardo, todos ellos vecinos de El Puerto, nos aportan en sus respuestas los siguientes datos objetivos: que el barco no lo ponía la ciudad por lo que quien no dispusiera de uno en propiedad, debía alquilarlo en 3 reales diarios; que la tripulación la componían cuatro hombres, arráez, proel y dos marineros, también a 3 reales diarios de salario cada uno; que cada vezino de Cádir paga de renta en el dicho passage 20 maravedíes y cada vezino del Puerto 24 y los demás 28 maravedíes; que, ciertamente, la bahía era paso muy peligroso y de munchos riesgos y que, finalmente, cuando hay flota para las Indias, se acrezienta la ganancia del dicho passaje por el concurso de gente que ba y biene en él. Sin embargo, en este caso quedaba descartado el argumento de los temporales y de la ausencia de flota por lo que, ya en noviembre de 1610, se otorga sentencia definitiva a favor de la ciudad y en contra de Gallardo ${ }^{61}$.

Para 1607, Juan Álvarez Paje, regidor y diputado entonces de rentas, se verá obligado a rematarla por sólo 750 dado que nadie ofreció más. ${ }^{62}$ Este valor es estable en adelante. Desde 1609, al menos, vuelve a ser Benito Sánchez su arrendador. Del mismo consta la siguiente incidencia. En octubre de 1612 se fugaba dejando una deuda de 600 ducados. Como su fiador, Pedro Saucedo, también estaba ausente, el cabildo dispone ejecución sobre sus bienes hasta saldar aquélla al tiempo que toma nota de quienes, en ausencia de los desaparecidos, estuvieron cobrando el pasaje. A su vez, insta a éstos a administrar el pasaje y dar cuenta de lo recaudado semanalmente cada sábado. ${ }^{63}$ Ello no es óbice para que, al año siguiente, vuelva a hacerse cargo del arriendo por 760 ducados pero, por cuanto el Cabildo advierte que al presente no iba a obtener las debidas garantías, se le exige más fianzas de la dicha renta y en falta dello se obligue de ir pagando por meses. ${ }^{64}$ Sin otro particular, todavía en 1615 Benito Sánchez seguía haciéndose cargo del pasaje por 700 ducados. ${ }^{65}$

En cuanto a los servicios de las barcas de Santi Petri y de Río Arillo, menos lucrativos con diferencia, eran indispensables para las comunicaciones de tierra adentro. Entrando por Puente Suazo y atravesada cómodamente La Isla, el caño de Arillo, con mayor o menor fondo según la marea, cerraba el tránsito y, si se venía desde las localidades de la banda atlántica, pasando por Chiclana y no queriendo subir hasta dicho puente, se topaban con el considerable cauce del de Santi Petri. Por ello fue necesario el permanente interés en mantener en buen uso tales enclaves.

\footnotetext{
${ }^{61}$ Ibidem.

${ }^{62}$ AHMC, AACC, $C^{\circ}$ de 5 de febrero de 1607, L 4, f. 91 r.

${ }^{63}$ AHMC, AACC, $\mathrm{C}^{\circ}$ de 15 de octubre de 1612 , L 5, f. $341 \mathrm{v}$.

${ }^{64}$ AHMC, AACC, $C^{\circ}$ de 11 de febrero de 1613, L 6, ff. 50r. y v.

${ }^{65}$ AHMC, AACC, $C^{\circ}$ de 13 de febrero de 1615, L 7, f. 249r.
} 
Del uso de la barca de Santi Petri consta un exclusivo disfrute por el Duque de Medina Sidonia y, al parecer, un pleito ganado por el mismo en $1575,{ }^{66}$ asunto siempre polémico en su resolución. Así, en el cabildo, ya antes citado, del dos de noviembre de 1596 la çiudad acordó que se ponga cobro a la barca del río de Santi Petro, término desta çiudad, para que aya passo por alli para conduçir el bastimento que a esta çiudad viene por tierra..${ }^{67}$ En una semana, tras buscarla, se localiza la barca y a quien se haga cargo de la misma. A éste se le darán 6 ducados para aderezarla y, al tiempo, se comprometerá a rendir el servicio por los dos años siguientes sin abonar cargo alguno. Transcurridos éstos sí deberá pagar 100 ducados anuales. ${ }^{68}$ Además, para su sustento y mantenimiento de la barca, se le otorga ocupación, una de las vigilancias, guardas, que Cádiz sostiene en dicho lugar. ${ }^{69}$ Esto, por otra parte, refleja un uso anterior y constante de la barca por la ciudad, al margen del que la villa de Chiclana y el Duque llegaban a tener. Tanto es así que, en enero de 1619, el gobernador intenta echar a los que llevaban el servicio dicho año y que ya habían pagado 100 ducados anuales y 50 más, gastados en adobar la casa del sitio y poner a su costa la barca. Entonces los barqueros contratados pidieron amparo a la ciudad por ser como somos pobres y el Concejo se dispuso a buscar la executoria questa çiudad tiene tocante a la dicha barca de Santipetro y los demás papeles..." En el consiguiente proceso se aludirá a que, en 20 de julio de 1598, Cádiz había obtenido una nueva ejecutoria dado que la que tenían de antes se había quemado junto a todo el archivo en 1596 con lo que se ratificaba el seguir poniendo barca en el lugar pese a la oposición manifiesta del Duque. Finalmente, dada sentencia, en septiembre se leía en cabildo la Real Provisión favorable tocante a la barca de Santi Petro. ${ }^{70}$ En suma, el uso de la barca de Santi Petri por parte de Cádiz venía a ser inmemorial.

La barca de Río Arillo o Darillo, pese a su modesto rendimiento, era indispensable. Como paso obligado, el Duque de Medina Sidonia hace hincapié en la prevención a tener para que puedan entrar socorros rápidamente y que, para ello, hay que tener la barca tan en orden y alistada. ${ }^{71}$ Por ello, en los remates de sus arrendamientos se insiste en la necesidad de tener la barca en buen uso. En 1609 Francisco Ortiz, quien desde el año anterior se hizo cargo de la misma, aludía a que está vieja, llena de broma y varada, y que, además, el camino está

\footnotetext{
${ }^{66}$ BOHÓRQUEZ, op. cit., pp. 180, 210-211.

${ }^{67}$ AHMC, AACC, $C^{\circ}$ de 2 de noviembre de 1596, L 1, f. 4v.

68 “...Dos mil e dozientos y quarenta y quatro ms. pago a Miguel Sánchez por la ocupación y trabajo de usar la barca de Santi Petro para el pasaje desta ciudad por libramiento de ocho de noviembre del dicho año y carta de pago." AHMC, LPC, 1596, f. 25r.

${ }^{69}$ AHMC, AACC, $C^{\text {o }}$ de 8 de noviembre de 1596 , L 1, f. 6r.

${ }^{70}$ AHMC, AACC, $C^{\circ}$ de 18 de enero de 1619, L 10, ff. 103v.-104r. y C $C^{\circ}$ de 2 de septiembre de 1619, L 10, ff. $185 \mathrm{v} .-187 \mathrm{r}$.

${ }^{71}$ AHMC, AACC, C $C^{\circ}$ de 5 de mayo de 1629, L 14, f. 235 r.
} 
perdido porque los salineros echan los lodos en él y solicitaba que con brevedad se solucione esto como conviene al buen pasaje y despacho de los caminantes y servicio de las heredades. ${ }^{72}$

En 1616 Francisco Ortiz, al tiempo que manifiesta su profesión, molinero, indica que lleva este servicio desde dos años antes sin pagar nada pero a condición de aderezar el camino, tanto en la parte de Cádiz como en la de La Isla, a uno y otro lado del paso, hasta la heredady jardin de don Francisco Estopiñán, así como la barca, las compuertas con cadenas de bierro y el alcantarilla de madera que está en el dicho camino. ${ }^{73}$ Como se ve, bien como principal o como fiadores, los barqueros pertenecen a la zona y, naturalmente, sus profesiones son las propias de un lugar caracterizado por la explotación de salinas y por la existencia de, al menos, dos molinos de marea, uno de ellos en Río Arillo. Salineros son, en fin, Juan Fernández y sus fiadores, Diego Alonso y Juan Fernández, quienes se hacen cargo en $1599 .{ }^{74}$ El mismo Juan Fernández, ya en 1605, en su puja de 35 ducados menos 5 con las condiçiones de años pasados, añade la de no llevar de pasaje más de un maravedí por cada persona. ${ }^{75}$

Por concluir, con estos arriendos de los pasajes y barcas que comunican Cádiz con su entorno más inmediato, por de pronto la ciudad se asegura un beneficio con exclusividad de alcance local que, en mayor o menor medida, va a ser constante hasta su desaparición, ya entrado el siglo XVIII. Es un rédito que, por supuesto, descontadas las fluctuaciones de la economía, reflejadas en la tendencia de los precios citados, por la propia naturaleza del negocio queda expuesto a contratiempos. Un percance, por repetido, puede llegar a modificar las condiciones, fórmulas y pagos al uso en los contratos en beneficio del particular contratante, si el Concejo es razonable y, en parte, cuando otros proprios van resultando más lucrativos para la ciudad. Los casos observados, por demás, sirven para constatar una ocupación constante, propia de esta población que, pese a todo, por encima de los efectos inmediatos del saqueo y del declive general, inicia pronto su pausado crecimiento a comienzos del siglo XVII.

Es, igualmente, como parte del sector terciario, factor esencial en la actividad portuaria y, como nudo que conecta las poblaciones costeras próximas, ${ }^{76}$ síntoma de su curso vital. Al margen de las barcas de Arillo y Santi Petri, propios de la red viaria que termina en

\footnotetext{
72 AHMC, AACC, $C^{\circ}$ de 23 de enero de 1609, L 4, f. 248v.

${ }^{73}$ AHMC, AACC, $C^{\circ}$ de 20 de enero de 1616, L 8, f. 22r.

${ }^{74}$ AHMC, LRC, 1597, s.f., 8 de Enero de 1599.

75 Ibídem, s.f.

${ }^{76}$ Con abundante bibliografía pero para Galicia y centrado en el siglo XVIII, véase VÁZQUEZ LIJÓ, José Manuel: "Libertad versus monopolio. Los servicios de pasaje en el litoral gallego en el siglo XVIII", TST (Revista Transportes, Servicios y Telecomunicaciones) 11, 2006.
} 
la ciudad, los pasajes crean una especie de "navegación interior", ${ }^{77}$ consustancial a este abrigo que es la Bahía ${ }^{78}$ y a su corazón, Cádiz, genuina "ciudad marítima". ${ }^{79}$ Quienes protagonizan esta navegación son gentes de mar, ${ }^{80}$ marineros y arráeces las más de las veces que viven exclusivamente de su profesión ${ }^{81}$ pero, entre los que arriendan el pasaje para El Puerto, por su mayor precio e inversión, está cualquiera que quiera apostar por el negocio local, sin riesgos aparentes aunque sin los grandes beneficios a los que aspira la burguesía de negocios. ${ }^{82}$

El vehículo del pasaje es, con denominación genérica, ${ }^{83}$ el barco luengo, embarcación que, como un falucho, por sus dimensiones, capacidad, diseño, maniobrabilidad, velocidad, precio y mantenimiento se presta perfectamente a esta navegación de la Bahía, bien para carga y pasaje, bien para pesca o, por lógica, para ambas funciones. En general no disponen de superestructura o cubierta corrida sino de su propio seno o vaso, de proa a popa, para cargar en todo su buque. ${ }^{84}$ Para el uso de pasaje cuenta habitualmente con un número de bancos situados transversalmente, en el sentido de la manga. De su adaptación a las particularidades del sitio y del momento buena prueba es que van aumentando progresivamente su longitud y capacidad, pues llegan a pasar de cinco bancos, menos de 9 metros, a once bancadas a medida que fondea más tráfico atlántico en la Bahía. ${ }^{85}$ De este

${ }^{77}$ AZNAR VALLEJO, Eduardo: "Barcos y barqueros de Sevilla", Historia. Instituciones. Documentos $\mathrm{n}^{\mathrm{o}}$ 21, 1994, pp. 1-2.

78 "Arrière-pays", área de influencia o hinterland. PONSOT, Pierre: "En Andalousie occidentale: sistèmes de transports et dèveloppement (XVIe-XIXe siècles)", Annales 6, 1976, p. 1199. DÍAZ BLANCO, José Manuel: "Antes de 1717: la Casa de la Contratación en el Cádiz del Seiscientos", Studia Historica, v. 39, $\mathrm{n}^{\circ} 2,2017$, pp. 38-39.

${ }^{79}$ MARTÍNEZ SHAW, Carlos: "La ciudad y el mar. La ciudad marítima y sus funciones en el Antiguo Régimen", Manuscrits 15, 1997, pp. 266-271.

${ }^{80}$ BUSTOS RODRÍGUEZ, Manuel: Los siglos decisivos, Cádiz, 1990, pp. 108-109.

${ }^{81}$ En 1637, por real cédula, se pretende reducir el número de barcos luengos de Cádiz a sólo 11 y en mayo se les prohibe navegar bajo pena de 500 ducados, pérdida de ellos y "ocho años de galeras al remo sin sueldo". Suplicando a la ciudad, recuerdan que fueron "de socorro y aviso" cuando la flota inglesa hizo su intentona en 1625 y que "no conocemos otro oficio que éste para sustentar a la familia." AHMC, AACC, $\mathrm{C}^{\mathrm{o}}$ de 22 de mayo de 1637, L 19, ff. 79v.-81v.

${ }^{82}$ BUSTOS, Ibídem, pp. 90-91, 103-104, 120.

83 “....son el más ligero género de embarcación que se ha inventado.”, “... y de vna de las ordenanças del año 1591 que dize que sean barcos de 25 pipas los que huvieren de ir, y venir de aviso...", “... por cédula de primero de Noviembre de 1589, que en la costa de Nueva España se introduxessen Barcos luengos, como en Sanlucar, y que en ellos se embiassen los Avisos..." Una tonelada actual coincidiría con un tonel y éste con dos pipas. VEITIA LINAJE, Norte de la Contratación de las Indias Occidentales, Sevilla, 1672 (ed. Francisco DE SOLANO, Madrid, 1981). pp. 169, 221 y 223.

${ }^{84}$ Se alude a una "especie de barco luengo" en la ilustración $\mathrm{n}^{\mathrm{o}} 8$ del tratado manuscrito Pesca de perlas $y$ búsqueda de galeones de Pedro de Ledesma, escrito en 1623. No obstante los barcos "luengos" dibujados arbolan dos mástiles. En todo caso, en las ilustraciones quedan bien diferenciados barcas, "luengos" y fragatas. Véase PACHECO MORALES-PADRÓN, Marcos: "Proyectos de sondeo, dragado y limpieza del río Guadalquivir (siglos XVII y XVIII)", Americania $\mathrm{n}^{\circ} 5$, 2017, p. 288 (nota 43).

${ }^{85}$ Aquí, también denominados "barcos pequeños", dan una medida de 15 codos, medidos de "quilla limpia" o de caperol a caperol pero, a mediados del siglo XVII, ya sobrepasaban esta medida alcanzando los 27 codos. AHMC, AACC, $\mathrm{C}^{\mathrm{o}}$ de 5 de febrero de 1652, L 28, ff. 22r.-23r. Igualmente véase CARRASCO 
modo se convirtió en un eficaz medio de transbordar mercancías al abarloarse al costado de una nao o galeón y distraer así de la Aduana una parte cada vez mayor de la mercadería sujeta a inspección.

Era, definitivamente, uno de los protagonistas de estas aguas y una embarcación eficaz y segura, muy marinera. Y, no obstante, también podía naufragar de no mantenerla ni gobernarla de forma adecuada. Buena prueba de ello, por terminar, es la comunicación que el regidor Pedro de Chávez hizo en un cabildo de 1629 de que ya ha entendido la ciudad la grande desgracia que sucedió el domingo pasado con el barco del pasaje que va de esta ciudad a la del Puerto de Santa María en que se abogaron veinte y seis personas y lo que conviene que baya mucho cuidado que el dicho barco esté bien aparejado y amarinado y con buenos marineros y asi suplica a la ciudad lo acuerde, mande y ordene. Acordado en el Concejo, como no podía ser de otro modo, se hacía la lógica recomendación de que los pilotos de la babia tengan particular cuidado de lo que está referido que se guarde y cumpla y que [la ciudad] examine al arráezy marineros para saber si lo son y que se les notifique para que lo guarden y cumplan. ${ }^{86}$

GONZÁLEZ, María Guadalupe: Los instrumentos del comercio colonial en el Cádiz del siglo XVII (16501700), Madrid, 1996, pp. 157-158.

${ }^{86}$ AHMC, AACC, $C^{\circ}$ de 15 de septiembre de 1629, L 14, f. 271v. 


\title{
Apéndice Documental
}

\section{Documento 1}

\author{
1582, enero, 21. Cádiz \\ Pedro de Alcocer, vecino de Cádiæ, y Antonio Lópezy Andrés Rodríguez, como sus fiadores, se obligan a \\ pagar 650 ducados y 12 de prometido de la puja en la subasta de la renta del pasaje de Cádiz a El Puerto de Santa \\ María.
}

ARCHG, C 3.378, P 8, fols 1r.-2r.

En la çiudad de Cádiz, veinte e un días del mes de henero de mill e quinientos y ochenta e dos años.

En presenzia de mí, Gerónimo de Valenzuela, escriuano de su Magestad e del cabildo desta çiudad de Cádiz, e testigos de yuso escritos parezió presente Pedro de Alcozer, vezino desta çiudad, y dixo que, cunpliendo con lo ques obligado de dar fianzas en la postura que tiene fecha en la renta del pasaje desta çiudad que va a la uilla del Puerto de Santa María por este presente año en prezio de seiszientos e çinqüenta ducados con doze ducados de aprometido, como se conthiene en la postura que tiene fecha en este libro de rentas, dexando en su fuerza e vigor las demás obligaziones que tiene fechas y fianzas que tiene dadas en esta dicha postura y añadiendo fuerza a fuerza e contrato a contrato, dio consigo por sus fiadores y prinçipales obligados a Antonio López y Andrés Rodríguez, mercaderes vezinos desta çiudad, questán presentes, los quales //1v. lo açetaron e, juntamente con el dicho Pedro de Alcozer y de mancomún y el dicho Pedro de Alcozer con ellos y todos a boz de vno e cada vno dellos por sí e por el todo, renunçiando las leyes de duobus reis de bendi y el benefizio de la división y escursión y el de depositar las espensas y el autentica presente de fidejusoribus e todas las demás leyes, fueros e derechos que son e hablan en razón de la mancomunidad, como en ellas se contiene, se obligaron que, siendo en el dicho Pedro de Alcozer rematada la dicha renta del pasaje que va desta çiudad a la uilla del Puerto de Santa María este presente año de último remate, darán e pagarán a esta muy yllustre çiudad de Cádiz, o a su mayordomo que es o fuere en su nonbre, los dichos seiszientos e çinqüenta ducados en que ansí está fecha la dicha postura en el dicho Pedro de Alcozer con los dichos doze ducados de prometido, los quales pagarán por los terçios del año que son fin de abril e fin de agosto e fin de dizienbre cada terçio la terçia parte, pagados en esta çiudad de Cádiz bien e cunplidamente como maravedíes y auer de su Magestad e de su renta real. E se obligaron e prometieron de guardar e cunplir las condizión e condiziones con que hizo postura desta dicha renta Juan Ibáñez, vezino desta çiudad, en seis días del mes de henero deste año en que se declara los barcos e pasaje que a de dar el tal arrendador para yr a la dicha uilla del Puerto y la horden que a de tener. E de la propia forma e manera se obligauan e obligaron de lo ansí cunplir e guardar e pagar. Y, ansí mismo, guardarán e cunplirán todas las demás condiçiones //2r. e posturas e 
declaraçiones con que se a arrendado y arrienda esta dicha renta questán escritas en este libro de rentas y en el capitular de los fechos desta çiudad, como en ellas se conthiene, porque las an uisto, sauido y entendido y son ziertos sauidores dellas. Los quales dichos seiszientos e çinqüenta ducados pagarán, como esta dicho, llanamente como por maravedíes y auer de su Magestad e no pedirán desqüento della por razón de qualesquier enfermedades de peste o otras qualesquier que en esta çiudad, lo que Dios no quiera, subzeda, ni enbargo de naos e nauíos o barcos ni por otro qualquier caso fortuito, divino o vmano, ansí de tenporales malos como de otros que subzedan, aunque sea de los casos que acaezen una vez en mill años, que de ningún remedio de los que se pudieren aprouechar no quieren pedir desqüento alguno. E renunziaron de su fabor qualesquier leyes e la ley de Partida e hordenamiento real que sobrello habla.

E, para lo ansí cunplir e auer por firme, obligaron sus personas e bienes, auidos e por auer, y dieron poder a las justizias de su Magestad de qualesquier partes que sean para que les apremien a lo ansí cunplir como por cosa juzgada, e renunziaron qualesquier leyes que sean en su fabor e la ley que dize que general renunçiazión no vala.

Testigos que fueron presentes: Luzián Pinelo, clérigo, e Baltazar Rodríguez e Jerónimo Jaína de Valençuela, vezinos desta çiudad.

Y el dicho Antonio López lo firmó de su nonbre y, porque los dichos Pedro de Alcozer e Andrés Rodríguez dixeron que no sauían escreuir, lo firmó a su ruego el dicho Jerónimo Jaína.

E yo, el presente escriuano, doy fee que conozco a los dichos otorgantes. Antonio López. A su ruego e por testigo de Pedro de Alcozer e Andrés Rodríguez, Jerónimo Jaína Valenzuela.

Pasó ante mí, Jerónimo de Valenzuela, escriuano del cabildo.

E yo, Gerónimo de Valençuela, escriuano de su Magestad real e del cabildo de la muy noble e leal çiudad de Cádiz, fuy presente e lo fiz escriuir e fize aquí mío signo a tal, en testimonio de verdad. Jerónimo de Valençuela, escriuano del cabildo.

\section{Documento 2}

1582, noviembre, 18. Cádiz

Antonio López, vecino de Cádir, por si y por Andrés Rodriguez, y Aparicio Rodríguez, partícipes y compañeros arrendatarios en la renta del pasaje de Cádiz a El Puerto de Santa María, ante la justicia local expone las razones de su oposición a la ejecución de bienes que pretende el mayordomo de la ciudad por impago de parte de la renta.

ARCHG, C 3.378, P 8, fols 3v.-4v.

E después de lo susodicho en la dicha çibdad de Cádiz, en diez e ocho días del mes de nouienbre del dicho año de mill e quinientos e ochenta e dos años, ante el dicho señor alcalde mayor y en presenzia de mí, el dicho escriuano, e testigos de yuso escritos, parezió el dicho Antonio López 
y presentó vn escrito de opusizión y vn testimonio de prouança, signado y firmado de escriuano, y vn interrogatorio con ziertas preguntas en él ynsertas por el qual pidió se esaminen los testigos que presentare. E su tenor del dicho escrito e testimonio de prouança es el siguiente, y el dicho interrogatorio yrá delante en cabeza de su provanza.

Yllustre señor.

Antonio López, vezino desta çibdad, por mí e por Andrés Rodríguez e Aparizio Rodríguez, mis partízipes y conpañeros en la renta que tenemos arrendada desta çiudad del pasaje que della va a la uilla del Puerto de Santa María, por lo que a nos e a cada vno de nos toca, me opongo a la execuzión que en mis bienes //4r. se a fecho a pedimiento de Pedro de Riuera, como mayordomo desta çibdad, por zierta contía de marauedíes, el tenor de la qual dicha execuzión y sus autos aquí prosupuestos e resumidos, digo que, de la dicha execuzión, yo e los dichos mis conpañeros, auemos de ser dados por libres en nuestros bienes e la dicha execuzión por ninguna por las causas e fundamentos siguientes:

- Lo primero por todo lo general que aquí e por espreso e repetido.

- Lo otro porque la renta questa çibdad nos arrendó del pasaje que de hordinario suele yr della a la uilla del Puerto de Santa María, sobre que esta execuzión se funda, ni yo ni los dichos mis conpañeros no somos obligados a la pagar porque, como es público y notorio y por tal lo alego, en esta çibdad ouo desde diez y seis días del mes de abril, próximo pasado, hasta los veinte e siete días del mes de agosto deste presente año de ochenta e dos años en esta çibdad ouo muncha enfermedad del mal contajioso de peste y murieron en ella munchas personas y ouo ospitales y casas de convalezientes por cuya causa y ocasión en la uilla del Puerto de Santa María, ques la parte y lugar para donde el dicho pasaje se me arrienda, salieron los vezinos de la dicha uilla e las fregatas de las galeras de su Magestad questán en ella e ynpidieron y estorbaron el dicho día, diez y seis de abril pasado, la entrada del dicho pasaje en la dicha uilla e con mano armada le estorbaron el yngreso y tránsito de la dicha uilla. Y desde aquel día hasta los dichos veinte e siete de agosto pasado zerraron el trato e comunicazión, entrada e comerzio de la dicha uilla a esta çiudad, de tal manera que de ningún modo ni condizión se podía ni pudo entrar en la dicha uilla desta çiudad y para esto la dicha uilla del Puerto tuvo grandísimo recato, custodia e guarda fasta que después de que, Dios Nuestro Señor, fue seruido dar salud a esta çibdad, que fueron los dichos veinte e siete de agosto, tornaron a abrir la entrada en la dicha uilla con esta çiudad. Y pues lo susodicho fue por causa de la dicha enfermedad de peste que ouo en esta çiudad, lo qual fue caso //4v. fortuito e inpensado a que los honbres no podemos prevenir y por serlo, según derecho, estamos libres de pagar la dicha renta que se nos pide e 
porque fuemos executados que son por tienpo de quatro meses y diez e siete díass, como todo más largamente consta e pareçe por esta ynformazión fecha ante la justiçia desta çiudad de que hago presentazión en lo a mí y a los dichos mis conpañeros faborable.

- Lo otro porque pues esta çibdad nos arrienda el dicho pasaje que della va de hordinario a la dicha uilla del Puerto de Santa María en la qual, como dicho es, se nos estorbó el tránçito y entrada, trato y comunicazión y del dicho pasaje se a de sacar la renta para con ella pagar a esta çiudad el prezio en que me lo arrienda y siendo como es diretamente para yr a la dicha uilla y no a otra parte, zesando como zesó el trato de la dicha uilla a esta çiudad, que es la causa prinçipal para la dicha renta, zesa, asimismo, el efeto ques estar yo obligado e los dichos mis conpañeros a pagar cosa alguna de todo el dicho tienpo pues el dicho caso fortuyto e ynpensado nos releva dello.

- Por todo lo qual pido a vuestra merçed reboque y anule la dicha execución dándola por ninguna e a mí e a los dichos mis conpañeros e bienes por libres, declarando no ser obligados a pagar cosa alguna de la dicha renta por todo el dicho tienpo de los quatro meses y diez e siete días. Sobre que pido justiçia y el ofiçio de vuestra merçed ynploró y las costas protesto e juro, etc.

- Otrosí hago presentaçión deste ynterrogatorio para que por su tenor se esaminen los testigos que presentare el bachiller Françisco de Azeuedo.

\section{Documento 3}

1597, octubre, 6. Cádiz

Antonio López, vecino de Cádiz, fía a Andrés Rodríguezy a Francisca de Cuadros, su mujer, en la deuda de estos con la ciudad de resto de la renta del pasaje de Cádiz a El Puerto de Santa María que tuvieron arrendada entre 1594 y 1596, obligándose al pago de lo que dejaran de abonar.

AHPC, PNC, oficio 9, leg. 1.508, fols. 454v.-456r., ante Marcos de Ribera.

Sepan ${ }^{87}$ quantos esta carta vieren cómo yo, Antonio López, vezino desta çiudad de Cádiz, digo que ansí es que Andrés Rodríguez, mi cuñado, vezino desta çiudad de Cádiz, es deudor a esta

${ }^{87}$ Al margen izquierdo: Fianza. 
çiudad de Cádiz y a sus propios y rentas de çiento e diez e seismill e dozientos e noventa maravedíes de resto del arrendamiento de tres años de la renta que tuvo del passaje que va desta çiudad a la çiudad del Puerto de Santa María, que estos tres años se cunplieron en fin del año pasado de mill e quinientos e noventa e seis años e esta çiudad por hazer bien e buena obra a el dicho Andrés Rodríguez a por bien y conçiente questa cantidad de maravedíes el dicho Andrés Rodríguez se la pague çinqüenta ducados dellos en fin del mes de dizienbre primero venidero deste presente año e la cantidad restante que son noventa e sietemill e quinientos e noventa maravedíes dentro de tres años luego siguientes ques en fin de cada vn año la terçia parte que a de correr los dichos tres años dende primero de henero del año primero venidero de mill e quinientos e noventa e ocho años, que es en cada vna paga treinta e dos mill e quinientos e treinta maravedíes, que los dichos Andrés Rodríguez e Françisca de Quadros, su muger, se obligan a mancomún a la paga //455r. del dicho dinero a los dichos plazos e que obliguen e ypotequen a la paga e seguridad dello unas cassas que el dicho Andrés Rodríguez tiene en esta çiudad en la plaça de la Corredera della que tienen por linderos, de la vna parte, cassas de herederos de Diego de Aguiniga y, de la otra parte, cassas de Rodrigo Infante y que dé fiança y seguridad que las dichas cassas son valiosas a la dicha deuda y que si no lo fueren que el tal fiador pagará la dicha deuda. Y porque yo quiero hazer esta fiança y seguridad, por tanto, de mi voluntad y en la más bastante forma ques nesçesario e si es nesçesario, haçiendo como hago de deuda e negoçio ageno mío propio, sin ser nesçesario hazer contra los dichos Andrés Rodríguez e su muger e sus bienes ni contra alguno dellos execuçión ni otra diligençia alguna, de fuero ni de derecho, que todo lo renunçio y declarando, como declaro, que la dicha deuda de arriba se debe de resto de la dicha renta del pasaje en la forma arriba dicha y renunçiando el poder alegar lo susodicho no ser ansí ni otra cosa de mi fauor e si lo dixere o quisiere dezir que me no vala. $\mathrm{Y}$ a esto en espeçial renunçio la exençión de la pecunia e prueua de la paga, como en ellas se contiene. E yo me obligo que las dichas cassas que se ypotecan a la dicha deuda //455v son ziertas, seguras e baliosas a la dicha deuda de los dichos çiento e diez e seismill e dozientos e noventa maravedíes que en casso que para la cobrança de la dicha deuda se aya de hazer diligençia contra las dichas casas y se hiziere, las dichas casas baldrán la dicha cantidad y abrá en ellas de que se pagar la dicha deuda y que baldrán la dicha cantidad libre de obligasçión e ypoteca e tributo e si no baliere la dicha cantidad para que la dicha çiudad sea pagada que lo que faltare dello yo lo pagaré en reales de contado en esta çiudad de Cádiz e llanamente e sin pleito e como deudor líquido que dello me constituyo e para liquidasçión de como las dichas cassas se executaron y que no valen la cantidad libre para la paga de la dicha deuda basta el juramento del procurador mayor desta çiudad sin ser nesçesario otro recaudo alguno porque de lo demás queda relebado.

Para todo lo qual cumplir e auer por firme, según y en la manera que dicha es, obligó mi persona e bienes, auidos e por auer, e doy poder cumplido e bastante a todas e qualesquier justiçias e juezes que sean doquier e ante quien esta escriptura se presentaré e della se pidiere cunplimiento de justiçia para que me apremien a lo cunplir por execusçión e prisión fecha en mi persona e bienes 
como en otra manera //456r. que de derecho lugar aya, de todo bien e cunplidamente como si esto que dicho es ansí fuese juzgado e sentençiado por sentençia de juez conpetente passada en cossa juzgada. E renusçio el apelasçión e suplicasçión e qualesquier leyes de mi fauor que me no valan en esta razón e la general que dize que general renuçiaçión de leyes fechas non vala e con que se saque vna escriptura e más.

Ques fecha en la çiudad de Cádiz, en el escriptorio de mí, el escriuano público yuso escripto, en seis días del mes de ottubre año del Señor de mill e quinientos e noventa e siete años.

Testigos que fueron presentes: Alonso de Vreña e Gregorio de Arreze e Françisco Sánchez Ahumada, vezinos de Cádiz. Y el dicho otorgante lo firmó en el registro a quien yo, el dicho escriuano, conozco ${ }^{88}$.

Antonio López (rúbrica).

Passó ante mí, Marcos de Ribera, escriuano público (rúbrica) ${ }^{89}$.

\section{Documento 4}

1599, febrero, 19. Cádiz

Juan Bautista de Meneses, vecino de Cádiz, vende a Andrés Rodríguez, vecino de Cádiz, el barco luengo que sirve el pasaje de Cádiz a El Puerto de Santa María por 100 ducados.

AHPC, PNC, oficio 9, leg. 1.510, fols. 156v-157v., ante Marcos de Rivera.

Sepan ${ }^{90}$ quantos esta carta vieren como yo, Juan Baptista de Meneses, vezino desta çibdad de Cádiz, de mi gana e voluntad, otorgo e conozco que vendo e hago venta real a Andrés Rodríguez, vezino desta çibdad de Cádiz, presente, para él e para quien él quisiere, a saber, el barco que dizen el barco luengo que es el que sirve de passaje que va desta çibdad //157r. a la çibdad de El Puerto de Santa María, el qual le vendo con sus mástel y vela e timón e remos e xarcia e con todos los demás aparejos que tiene y que en qualquier manera paresçieren suyos y libre de carga, de obligasçión e ypoteca porque no la tiene e por presçio e contía de çient ducados de a honze reales cada vn ducado que por conpra del dicho barco el dicho Andrés Rodríguez me a pagado en reales de contado e yo los he resçibido. E dellos me doy por contento a mi voluntad. Y en razón del resçibo, renusçio la esençión de la pecunia e prueva de la paga.

E desde oy para en adelante me desapodero de todo el derecho que tengo a el dicho barco y en el dicho derecho apodero y entrego a el dicho Andrés Rodríguez e le doy la poseçión dél. Y en

\footnotetext{
${ }^{88}$ Salvado de yerro: enmendado Andrés Rodríguez.

${ }^{89}$ Bajo la suscripción del escribano: derechos dos reales.

${ }^{90}$ Al margen izquierdo: Venta de barco.
} 
señal de poseçión pido a el presente escriuano le entregue esta escriptura signada para que la tenga por título de lo en ella contenido, para que el dicho Andrés Rodríguez aya para él el dicho barco e haga dél como de cossa suya. El qual dicho barco declaro que es el propio que el dicho Andrés Rodríguez a mí me vendió e se lo buelvo de la manera que yo lo tengo e poseo e como él me lo vendió e sin le quedar obligado a saneamiento alguno porque lo toma a su riesgo, sólo le aseguro que por deuda que yo deua no le será enbargado el dicho barco ni puesto sobre él pleito y si lo fuere que yo tomaré la defenssa dél luego que se me requiera y le sacaré dello a pazz e a saluo de manera que por ello no pague cossa alguna. Para todo lo qual cunplir, según dicho es, obligo mi persona e bienes, avidos e por aver.

E yo, el dicho Andrés Rodríguez, estando presente, açeto esta venta e me contento con el saneamiento que el dicho Juan Baptista de Meneses me haze sin yo querer otro alguno. E por la presente me hago cargo del dicho barco e declaro que lo tengo en mi poder y dél me //157v. doy por entregado y, en (razón de su resçibo, renusçio?) la esençión de la pecunia e prueva del entrego. Para todo lo qual cunplir, obligo mi persona e bienes, avidos e por aver.

$\mathrm{E}$ anbas partes damos poder a las justiçias para que me ${ }^{91}$ apremien a lo cunplir por execuçión e prisión y en otra manera como por sentençia de juez conpetente passada en cosa juzgada. E renusçiamos qualesquier ley e leyes de $\mathrm{mi}^{92}$ fauor, que me no valan, e la general que dize que general renusçiaçión no vala.

Que es fecha en la çibdad de Cádiz, en el escriptorio del escriuano público yuso escripto, en diez e nueue días del mes de hebrero, año del Señor de mill e quinientos e noventa e nueue años.

Testigos: Diego de Robles y Andrés Colen e Françisco Sánchez Ahumada, vezinos de Cádiz. Y el dicho Juan Baptista lo firmó e por el dicho Andrés Rodríguez lo firmó el dicho Françisco Sánchez. E yo, el dicho escriuano, conozco a los otorgantes.

Juan Batista de Meneses (rúbrica). A ruego del sobredicho, Françisco Sánchez Ahumada (rúbrica).

Passó ante mí, Marcos de Ribera, escriuano público (rúbrica $)^{93}$.

\footnotetext{
${ }^{91}$ Sic.

${ }^{92}$ Sic.

${ }^{93}$ Bajo la suscripción del escribano: $\sin$ derechos.
} 